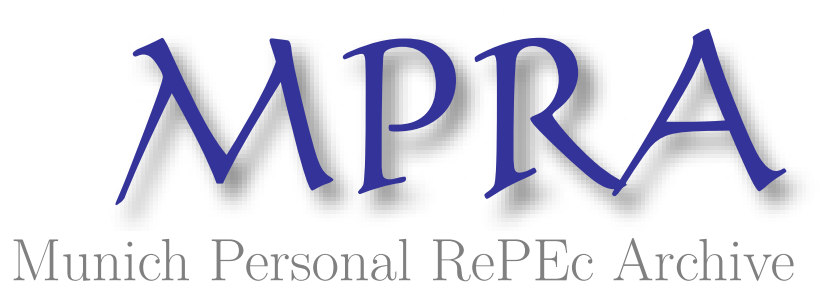

\title{
CEO Compensation, Pay Inequality, and the Gender Diversity of Bank Board of Directors
}

Owen, Ann L. and Temesvary, Judit

Hamilton College, Federal Reserve Board of Governors

May 2018

Online at https://mpra.ub.uni-muenchen.de/87007/

MPRA Paper No. 87007, posted 03 Jun 2018 20:29 UTC 
CEO Compensation, Pay Inequality, and the Gender Diversity of Bank Board of Directors

\author{
Ann L. Owen \\ Hamilton College \\ Judit Temesvary ${ }^{1}$ \\ Federal Reserve Board
}

May 2018

\begin{abstract}
Greater gender diversity on bank board of directors is associated with higher compensation inequality because CEOs at these banks have higher base salary. This effect disappears during the financial crisis, largely due to adjustment of non-salary compensation.
\end{abstract}

Key Words: CEO compensation; gender diversity, board of directors

JEL Codes: G2, G3, J3

\footnotetext{
${ }^{1}$ The views expressed in this paper are solely those of the authors and shall not be interpreted as reflecting the views of the Board of Governors of the Federal Reserve System. We are grateful to Paul Hagstrom and Stephen Wu for helpful comments.
} 


\section{Introduction}

CEO compensation and pay inequality at financial firms were highlighted as important policy issues in the wake of the financial crisis. Compensation schemes for bank CEOs could lead banks to take excessive risks which ultimately could have real economic impact. In this paper, we examine the determinants of CEO compensation and pay inequality in large US bank holding companies, with a particular focus on the role of the gender composition of the board of directors.

Our work is related to two different strands of the economics literature. One strand looks at the influence of the board of directors on CEO compensation (Faulkender and Yang, 2010; Ayadi and Boujelbene, 2013). This literature has found a role for the power of the CEO and several characteristics of the board. A second strand of the literature examines the performance effects of gender diversity on bank board of directors (Adams and Mehran, 2012; Garcia-Meca et al, 2015). While this literature has found mixed results, recently, Owen and Temesvary (forthcoming) reconcile these results by showing that positive performance benefits of gender diversity occur only when 1) there is a threshold number of women on the board, and 2) the bank is well managed.

Our results complement the findings in both strands of the previous literature, showing that another aspect of board characteristics, gender diversity, increases CEO compensation. Furthermore, we find some evidence that this impact is nonlinear, supporting previous results that show that the impact of diversity is context dependent (Joshi and Roh, 2009).

\section{Data and Methods}

Our data set contains annual observations of bank and board characteristics from 87 bank holding companies (henceforth, banks) in the United States over the time period 1999-2015. The data is drawn from multiple sources: Boardex, Bankscope, Compustat, and CRSP. Data availability restricts our sample to the larger banks; the banks in our sample hold around 40 percent of all bank holding company assets in the United States.

To measure gender diversity, we use the Blau Index (Blau 1977), defined as follows:

$$
B=\left[1-\sum_{g=1}^{G} P_{g}^{2}\right] \times 100
$$


where $P$ is the fraction of directors of gender $g$. It reaches its maximum when the shares of men and women on the board are equal. Because no bank in our sample has a female share greater than 50 percent, the Blau Index is highly correlated with the percent of women on the board. The average female share in our sample is about 10 percent, corresponding to an average Blau Index of about 18.

To explore the relationship between gender diversity and pay inequality, we estimate the following equation:

$$
Y_{t}^{b}=\alpha_{0}+\alpha_{1} X_{t-1}^{b}+\alpha_{5} Z_{t-1}^{b}+\alpha_{6} S_{t-1}^{b}+\alpha_{7} T_{t}+\alpha_{8} B_{b}+\varepsilon_{t}^{b}
$$

In Equation 2, $Y_{t}^{b}$ denotes a ratio of CEO compensation to average staff compensation and $X_{t-1}^{b}$ is the lagged value of the Blau Index. In the numerator of $Y_{t}^{b}$, we use three different CEO pay metrics: total compensation of the CEO, the base salary of the CEO, and bonuses paid to the CEO. The denominator, average staff compensation, is the mean value of total compensation to all workers except the CEO, calculated from aggregate values from financial reporting. In some specifications, we also include the square of the Blau Index $\left(X_{t-1}^{b}\right)^{2}$ to allow for nonlinear effects of gender diversity.

Equation 2 also controls for bank and board characteristics. $Z_{t-1}^{b}$ is the vector of board characteristics which includes: Board Size, Average Age of Board Members, and the natural logarithm of Average Director Compensation of Board Members, Average Wealth of Board Members, Average Years on Bank Boards, Average Number of Boards Served, and Average Number of Years on Any Board. The vector of bank balance sheet characteristics in $S_{t-1}^{b}$ contains the Loan to Deposit Ratio, log of Total Assets, Return on Average Equity, and the Risk-Weighted Capital Ratio. Furthermore, $B_{b}$ and $T_{t}$ represent bank and year fixed effects. We use lagged values of all independent variables to mitigate concerns about reverse causality. Finally, because there are some outliers in the CEO pay ratio, we report results after a $1 \%$ and 99\% winsorization from below and above, respectively.

\section{Results}

Table 1 displays results for the estimation of Equation 2. Column 1 examines total compensation of the CEO divided by compensation of the average worker. In Column 1, the Blau index enters positively, 
suggesting that greater gender diversity is associated with greater compensation inequality. Interestingly, although many of the bank and year fixed effects (not shown on the table) are statistically significant, none of the bank balance sheet traits that vary from year to year are. A few of the board characteristics are significant, with younger boards and boards with directors that have more years of experience on bank boards having higher pay inequality. Finally, we find no evidence of a quid pro quo between directors and CEOs: there is no evidence that directors that are compensated more for their board service reward the CEO with higher compensation.

The result that more gender diversity is related to higher pay inequality is somewhat surprising, given the experimental literature that concludes that women have a greater preference for equality (Croson and Gneezy, 2009). To gain better insight into this result, we examine different components of CEO compensation, starting first with the base salary (Column 2). While bonuses for short-term performance could be incentives for bank CEOs to take greater short-term risk, the base salary provides less direct incentives for such risk-taking. The results in Column 2 support the conclusion that greater gender diversity is associated with greater inequality when that inequality is measured using the ratio of the CEO salary to the average worker compensation.

To gain further understanding of the higher inequality, we examine the determinants of the log of CEO salary at these banks. The results in Column 3 mirror those in Column 2, suggesting that the higher inequality is a result of a higher numerator in our CEO pay ratio: more gender-diverse boards pay bank CEOs higher base salaries. This could be consistent with greater risk aversion if it were a result of base salaries being a more important component of overall compensation. However, in results not reported in detail here, we do not find any statistically significant effect of gender diversity on the share of compensation that is attributable to base salary vs. bonus pay.

Higher CEO salary could be an indication that the CEO has more power. The number of women on these boards is small; we do not know how powerful they are in boardroom discussions. It is possible that when there are only a small fraction of women on the board, their voices are weaker which weakens the board overall and gives the CEO more power (Usman et al, 2018). However, as the gender diversity of 
the board expands, raising the influence of the female board members, the overall strength of the board may also increase (Karpowitz and Mendelberg, 2014; Owen and Temesvary, 2018). In fact, the negative and significant coefficient on the square of the Blau Index in Column 4 shows that there is a nonlinear effect of gender diversity on the CEO salary. As gender diversity increases, its impact on CEO salary diminishes. Thus, our findings of a positive relationship between gender diversity and CEO pay may not be indicative of the preferences of the individual female board members, but rather the dynamics of having a small number of women on the board.

Unfortunately, our sample is dominated by banks with two or less women on their boards and does not contain any banks with board gender equality; we are unable to directly test how CEO compensation changes when women are not substantially in the minority. However, the nonlinear relationship between diversity and CEO pay is consistent with the functioning of the board improving when gender representation is more equal. This phenomena has been demonstrated with experimental results, showing that business team performance is highest with gender equality (Hoogendorn et al., 2013). It is also consistent with results in the organizational psychology literature that suggest that in male-dominated professions, an initial increase in gender diversity has a negative impact (Joshi and Roh, 2009).

We seek further insight into the reward for risk-taking by examining how gender diversity of the board of directors is related to pay inequality during the financial crisis. We create an indicator variable for the years of the crisis (2008 and 2009) and interact it with all of our independent variables, including the Blau Index, to examine if there is a differential effect during this time. We examine the overall compensation ratio (Column 5), and its components: the base salary ratio (Column 6) and the bonus ratio (Column 7). In Column 5, the statistically significant negative coefficient on the Blau Index interacted with the crisis dummy is almost equal to the positive coefficient on the Blau Index, indicating that the positive effect of gender diversity on pay inequality is erased during the crisis. The insignificance of the Blau Index interacted with the crisis dummy in the base salary ratio estimation (Column 6) suggests that this effect occurred through adjustment of bonus compensation. Results in Column 7 confirm this idea. The negative and significant coefficient on the interaction of the Blau Index and the crisis dummy in the estimation of 
the $\mathrm{CEO}$ bonus ratio suggests that $\mathrm{CEO}$ bonuses decreased more during the crisis at banks with more gender diversity. More gender-diverse boards were more willing to punish CEOs during times of extreme poor performance. If gender diversity is linked to CEO power but bank CEOs lost that power during the financial crisis, this result is consistent with lower CEO power reducing CEO compensation.

\section{Conclusion}

Our work finds evidence that increased gender diversity of bank boards is associated with higher levels of base pay earned by CEOs and more compensation inequality overall. We achieve these results by controlling for bank fixed effects as well as several measures of bank performance, allowing us to rule out many explanations that are related to the performance effects of gender diversity or characteristics of banks that might have more women on their boards. A possible interpretation is that our results are indicative of complex boardroom dynamics and their influence on CEO power when women are a significant minority on the board.

\section{References}

Adams, Renee B. and Hamid Mehran (2012). "Bank board structure and performance: Evidence for large bank holding companies," Journal of Financial Intermediation 21, 243-267.

Ayadi, Nesrine and Younes Boujelbene, 2013, "The influence of the board of directors on the executive compensation in the banking industry," Global Business and Management Research: An International Journal 5(2): 83-90.

Blau, Peter M. (1977). Inequality and heterogeneity. New York, NY: Free Press.

Croson, Rachel, and Uri Gneezy (2009) “Gender differences in preferences,” Journal of Economic Literature 47(2), 448-74.

Faulkender, Michael and Jun Yang, 2010, "Inside the black box: The role of composition of compensation peer groups," Journal of Financial Economics 96: 257-270.

Garcia-Meca, Emma, Isabel-Maria Garcia-Sanchez and Jennifer Martinez-Ferrero (2015). "Board diversity and its effects on bank performance: An international analysis," Journal of Banking \& Finance 53 (April), 202-14.

Hoogendorn, Sander, Hessel Oosterbeek, and Mirjam van Praag (2013). "The Impact of Gender Diversity on the Performance of Business Teams: Evidence from a Field Experiment," Management Science 59(7): 1514-1528. 
Joshi, Aparna and Huyntak Roh (2009). "The role of context in work team diversity research: A metaanalytic review," Academy of Management Journal 52(3): 599-627.

Karpowitz, C., \& Mendelberg, T. (2014). The Silent Sex: Gender, Deliberation, and Institutions. Princeton University Press.

Owen, Ann and Judit Temesvary, 2018, "The performance effects of gender diversity on bank boards," Journal of Banking and Finance 90: 50-63.

Usman, Muhammad, Junrui Zhang, Muhammad Umar Farooq, Muhammad Abdul Majid Makki, and Nanyan Dong, 2018, “Female directors and CEO power,” Economics Letters 165: 44-47. 
Table 1

\begin{tabular}{|c|c|c|c|c|c|c|c|}
\hline & (1) & (2) & (3) & (4) & (5) & (6) & (7) \\
\hline $\begin{array}{l}\text { VARIABLES (all variables } \\
\text { lagged) }\end{array}$ & $\begin{array}{c}\text { CEO } \\
\text { Compensation } \\
\text { Ratio } \\
\end{array}$ & $\begin{array}{l}\text { CEO } \\
\text { Salary } \\
\text { Ratio } \\
\end{array}$ & $\begin{array}{l}\text { Ln(CEO } \\
\text { Salary) }\end{array}$ & $\begin{array}{l}\text { Ln(CEO } \\
\text { Salary) }\end{array}$ & $\begin{array}{c}\text { CEO } \\
\text { Compensation } \\
\text { Ratio } \\
\end{array}$ & $\begin{array}{l}\text { CEO } \\
\text { Salary } \\
\text { Ratio } \\
\end{array}$ & $\begin{array}{c}\text { CEO } \\
\text { Bonus } \\
\text { Ratio } \\
\end{array}$ \\
\hline Blau & $\begin{array}{c}0.760^{* *} \\
(0.376)\end{array}$ & $\begin{array}{c}0.0688^{* * *} \\
(0.0168)\end{array}$ & $\begin{array}{c}0.00592^{* * *} \\
(0.00215)\end{array}$ & $\begin{array}{c}0.0148 * * * \\
(0.00536)\end{array}$ & $\begin{array}{l}0.802^{*} \\
(0.410)\end{array}$ & $\begin{array}{c}0.0733 * * * \\
(0.0175)\end{array}$ & $\begin{array}{c}0.0257 \\
(0.0660)\end{array}$ \\
\hline Blau Squared & & & & $\begin{array}{l}-0.000213 * \\
(0.000111)\end{array}$ & & & \\
\hline Blau*crisis & & & & & $\begin{array}{c}-0.816^{* *} \\
(0.402)\end{array}$ & $\begin{array}{c}0.0214 \\
(0.0322)\end{array}$ & $\begin{array}{c}-0.311 * * * \\
(0.106)\end{array}$ \\
\hline \multicolumn{8}{|l|}{ Board Characteristics } \\
\hline$\overline{\text { Board size }}$ & $\begin{array}{l}1.504 \\
(1.054)\end{array}$ & $\begin{array}{c}0.0854 \\
(0.0521)\end{array}$ & $\begin{array}{c}0.00306 \\
(0.00416)\end{array}$ & $\begin{array}{c}0.00278 \\
(0.00420)\end{array}$ & $\begin{array}{c}1.804 \\
(1.101)\end{array}$ & $\begin{array}{c}0.0677 \\
(0.0543)\end{array}$ & $\begin{array}{c}0.416 \\
(0.427)\end{array}$ \\
\hline $\ln$ (Director Compensation) & $\begin{array}{c}1.069 \\
(3.902)\end{array}$ & $\begin{array}{l}0.0736 \\
(0.178)\end{array}$ & $\begin{array}{l}-0.00668 \\
(0.0268)\end{array}$ & $\begin{array}{l}-0.00657 \\
(0.0264)\end{array}$ & $\begin{array}{l}-0.194 \\
(3.862)\end{array}$ & $\begin{array}{l}0.0779 \\
(0.175)\end{array}$ & $\begin{array}{l}1.129^{*} \\
(0.607)\end{array}$ \\
\hline Average Age of Board & $\begin{array}{l}-145.1 * \\
(87.41)\end{array}$ & $\begin{array}{l}-7.724^{*} \\
(4.537)\end{array}$ & $\begin{array}{l}-0.323 \\
(0.420)\end{array}$ & $\begin{array}{l}-0.322 \\
(0.423)\end{array}$ & $\begin{array}{c}-224.8 * * \\
(90.18)\end{array}$ & $\begin{array}{l}-1.470 \\
(4.338)\end{array}$ & $\begin{array}{l}-23.25 \\
(15.26)\end{array}$ \\
\hline $\begin{array}{l}\ln (\text { average years on bank } \\
\text { boards) }\end{array}$ & $\begin{array}{c}67.66 * * \\
(29.03)\end{array}$ & $\begin{array}{l}3.160^{*} \\
(1.688)\end{array}$ & $\begin{array}{c}0.149 \\
(0.144)\end{array}$ & $\begin{array}{l}0.148 \\
(0.145)\end{array}$ & $\begin{array}{l}58.21^{*} \\
(31.13)\end{array}$ & $\begin{array}{r}3.185^{* *} \\
(1.358)\end{array}$ & $\begin{array}{c}17.38 * * * \\
(5.537)\end{array}$ \\
\hline $\ln ($ average number of boards) & $\begin{array}{c}13.53 \\
(20.67)\end{array}$ & $\begin{array}{l}-0.371 \\
(1.394)\end{array}$ & $\begin{array}{l}-0.112 \\
(0.167)\end{array}$ & $\begin{array}{l}-0.131 \\
(0.166)\end{array}$ & $\begin{array}{c}9.946 \\
(22.26)\end{array}$ & $\begin{array}{l}-0.323 \\
(1.247)\end{array}$ & $\begin{array}{c}2.977 \\
(3.471)\end{array}$ \\
\hline $\ln ($ average years on any board) & $\begin{array}{l}-0.761 \\
(14.13)\end{array}$ & $\begin{array}{l}2.047 * * \\
(0.858)\end{array}$ & $\begin{array}{c}0.109 \\
(0.0783)\end{array}$ & $\begin{array}{c}0.105 \\
(0.0783)\end{array}$ & $\begin{array}{c}17.63 \\
(17.56)\end{array}$ & $\begin{array}{c}1.035 \\
(0.772)\end{array}$ & $\begin{array}{l}-1.942 \\
(2.270)\end{array}$ \\
\hline \multicolumn{8}{|l|}{ Bank Characteristics } \\
\hline$\overline{\ln \text { (total assets) }}$ & $\begin{array}{c}5.248 \\
(13.22)\end{array}$ & $\begin{array}{c}2.427 * * * \\
(0.586)\end{array}$ & $\begin{array}{c}0.275 * * * \\
(0.0747)\end{array}$ & $\begin{array}{c}0.259 * * * \\
(0.0721)\end{array}$ & $\begin{array}{c}9.008 \\
(13.53)\end{array}$ & $\begin{array}{c}2.517 * * * \\
(0.571)\end{array}$ & $\begin{array}{c}2.245 \\
(1.782)\end{array}$ \\
\hline Risk-weighted capital ratio & $\begin{array}{l}-0.794 \\
(1.021)\end{array}$ & $\begin{array}{c}0.0620 \\
(0.0755)\end{array}$ & $\begin{array}{r}-0.00551 \\
(0.0112)\end{array}$ & $\begin{array}{c}-0.00494 \\
(0.0109)\end{array}$ & $\begin{array}{c}0.440 \\
(1.122)\end{array}$ & $\begin{array}{c}0.0428 \\
(0.0744)\end{array}$ & $\begin{array}{c}0.402 \\
(0.250)\end{array}$ \\
\hline Loans to deposits ratio & $\begin{array}{l}-9.222 \\
(26.67)\end{array}$ & $\begin{array}{l}-0.0250 \\
(1.149)\end{array}$ & $\begin{array}{c}0.0173 \\
(0.0912)\end{array}$ & $\begin{array}{l}0.00681 \\
(0.0904)\end{array}$ & $\begin{array}{l}-13.54 \\
(26.49)\end{array}$ & $\begin{array}{c}0.320 \\
(1.133)\end{array}$ & $\begin{array}{l}-7.624 \\
(4.922)\end{array}$ \\
\hline Return on average equity & $\begin{array}{c}0.223 \\
(0.258)\end{array}$ & $\begin{array}{l}-0.00947 \\
(0.0216)\end{array}$ & $\begin{array}{l}-0.000205 \\
(0.00207)\end{array}$ & $\begin{array}{l}-0.000264 \\
(0.00206)\end{array}$ & $\begin{array}{c}0.294 \\
(0.591)\end{array}$ & $\begin{array}{c}-0.0287 \\
(0.0309)\end{array}$ & $\begin{array}{c}0.119 \\
(0.0895)\end{array}$ \\
\hline $\begin{array}{l}\text { Year Fixed Effects } \\
\text { Bank Fixed Effects } \\
\text { Crisis Interaction with All }\end{array}$ & $\begin{array}{l}\text { yes } \\
\text { yes }\end{array}$ & $\begin{array}{l}\text { yes } \\
\text { yes }\end{array}$ & $\begin{array}{l}\text { yes } \\
\text { yes }\end{array}$ & $\begin{array}{l}\text { yes } \\
\text { yes }\end{array}$ & $\begin{array}{l}\text { yes } \\
\text { yes }\end{array}$ & $\begin{array}{l}\text { yes } \\
\text { yes }\end{array}$ & $\begin{array}{l}\text { yes } \\
\text { yes }\end{array}$ \\
\hline Independent Vars. & no & no & no & no & yes & yes & yes \\
\hline $\begin{array}{l}\text { Observations } \\
\text { R-squared }\end{array}$ & $\begin{array}{c}732 \\
0.666 \\
\end{array}$ & $\begin{array}{c}735 \\
0.775 \\
\end{array}$ & $\begin{array}{c}688 \\
0.836 \\
\end{array}$ & $\begin{array}{c}688 \\
0.837 \\
\end{array}$ & $\begin{array}{c}732 \\
0.685 \\
\end{array}$ & $\begin{array}{c}735 \\
0.778 \\
\end{array}$ & $\begin{array}{c}402 \\
0.937 \\
\end{array}$ \\
\hline
\end{tabular}

Robust standard errors in parentheses, $* * * \mathrm{p}<0.01, * * \mathrm{p}<0.05$, $* \mathrm{p}<0.1$ 